\title{
Vindicating Sustainable Leisure in Kuningan, West Java, Indonesia
}

\author{
Hengky, S. H. (Corresponding author) \\ Director, SHINE Institute \\ Associate Professor, Triguna, School of Economics \\ E-mail: hengky_halim@yahoo.com.au
}

\begin{abstract}
Received: September 26, 2014 Accepted: October 17, $2014 \quad$ Published: October 20, 2014
doi:10.5296/ijssr.v3i1.6473 URL: http://dx.doi.org/10.5296/ijssr.v3i1.6473
\end{abstract}

\begin{abstract}
The aim of this research is to vindicate the development of sustainable leisure in Kuningan and responding the statement of the Indonesian minister of tourism by vindicating sustainable leisure in Kuningan, West Java, Indonesia. This statement was so important for realizing the development of sustainable tourism. This study found four potential sustainable tourism based on sustainable leisure in Kuningan District: Linggarjati Natural Park is the most potential to be a sustainable leisure park; Archaeological Park Cipari is more potential to be a sustainable leisure park; Waterfall Ciputri is potential to be a sustainable leisure waterfall; and Lake Remis is also potential to be a sustainable leisure lake. This research found that social carrying capacity and social consensus become a big issue in improving appraisal and performance of sustainable leisure in Kuningan. At the same time, it could responding tourists' need and their expectation. However, developing and building an attraction designed to be a comprehensive spatial pattern, although the development of these facilities is not built all at once. However, with comprehensive planning, all the facilities will be built according to the design that was created from the beginning.
\end{abstract}

Keywords: Sustainable leisure, Local consensus, Appraisal, Social carrying capacity

\section{Introduction}

The tourism sector is a provider of employment opportunities that a dominant $10 \%$ of employment in Indonesia with 7.3 million direct labor and indirect 5 million people (Santosa, 2004). While, the number of tourist visits to Indonesia has increased each year. In 2013, it recorded 8.8 million the number of tourists who come to the archipelago. In 2014, the target is the range of 9.3 to 9.5 million the number of tourists (Farhan, 2014). 
Obviously, the data show that currently the growth of the tourism industry in Indonesia 1st semester 2014 has been reported to be $6.8 \%$, and its meaning that it has exceeded the national economic growth reaches $5.7 \%$ (Asdhiana, 2014).

Kuningan district and cities located in the eastern part of West Java, Indonesia. Kuningan is crossing the road that connects the city of Cirebon with Priangan East region and as an alternative to the center lane road that connects Bandung-Java with Central Java. It has varied landscape ranging from the lowlands to the highlands to the highest peak in West Java Ciremai the top of the mountain $(3,076 \mathrm{~m})$.

Kuningan regency, West Java province with an area of 1,178.57 km which lies at the foot of Mount Ciremai, in the northern part bordering Cirebon, in the eastern part bordering Brebes Central Java Province, in the southern part bordering the district of Cilacap - Central Java and Ciamis, and in the western part bordering Majalengka.

In vision Kuningan mainstay tourism sector is a potential that needs to be explored, developed and promoted. In addition to the beautiful natural Kuningan consists of mountains, hills, slopes, valleys or lake, the weather was cool between $18-30{ }^{\circ} \mathrm{C}$ and in support of many cultures and diversity.

The aim of this research is to vindicate the development of sustainable leisure in Kuningan, and responding the statement of the Indonesian minister of tourism: "The tourism sector has become one of the foundations of the Indonesian people to improve their living standards and it must be fought for constantly. This statement was so important for realizing the development of sustainable tourism" (Asdhiana, 2014).

\section{Literature Review}

Recreational environmental conservation efforts are a challenge for the entertainment industry in taking action the company, but industry leaders, professional groups, and individuals can support the conservation of the environment. Sustainable landscape is a concept that is designed to reduce the use of environmental conflict and increased access to recreation and tourism, and the role of government agencies, to maintain the best service for the environment and promoting sustainable development of sports based economic regeneration (Gordon, 1991).

Sustainable leisure management is based on a sustainable approach is adapted based leisure park management to reduce the negative impact of sustainable leisure tips: strategies, tools and techniques in rural areas: consensus of the local community, environmental impact assessment, and capacity building destination. Sustainable leisure management: environmental management of tourism zoning system, standardization of each zone and its conflicts, and monitoring (Kirkbride, 1996).

In strengthening the strategy of sustainable leisure in college or in practice, is by expanding their area of discipline and practice to improve social awareness, and experience in sustainable leisure. Sustainable leisure-space created by the arrangement of both recreational and describe a variety of serious leisure perspective by emphasizing the importance of the 
social-cultural-historical experiences improve their understanding leisure (Stebbins, 2011).

Additionally, free time for leisure sustainable mobility activities aims to satisfy the needs of leisure travelers to avoid traffic. Sustainable recreational activities will be decreased in proportion to the increasing age of the tourists. Sustainable leisure activities are met as long as they traveled. Long-term sustainable leisure orientation and location of the workplace can affect their satisfaction and provide space for recreation election during their spare time. In addition, short-term, sustainable leisure's quality depends on the proximity of sustainable leisure and sport quality that offers the possibility of spatial prerequisites (Schuttemeyer, Fobker, Ramatschi, \& Grotz, 2004).

One of the activities is the sustainable mobility: cycling as concerned with environmental issues, and security in many ways, according to the different ways each individual; and intrinsic motivation factors. The motivational factors include: relaxation activities, social gatherings, stimulus, exploring the physical challenge. Continuous cycling based leisure activities generate the hierarchical value map that characterizes the key relationships with experience (Ho, Liao, Huang, \& Chen, 2014).

The environmental impact of leisure activities is calculated based on the expenditure of money and energy use, use of recreation time, and goods consumed. Energy consumption of leisure activity is measured in units of energy per amount of expenditure, $20 \%$ lower than the consumption of everyday household, but it was $38 \%$ higher than public consumption. The growth of mobility in patterns of leisure becomes a significant problem. Strategies to reduce the environmental impact of leisure consumption depends on the volume and patterns of consumption, leisure productivity, and utilizing it in a way to educate the public (All, 2011).

One way to encourage behavior change in a continuous free time using social marketing, which has been successfully used in the context of tourism. Social marketing focuses on behavioral change by guiding the individual's perception of: the cost, time, and convenience. Attitudes and behavior of environmental care will reduce the environmental impact (Wooler, 2014). Meanwhile, Edgington (2013) reviewed 50 years of World Leisure Organization activities, where he has been framed: leadership; services and activities; sources of financial support; formation; major policy statement; major publications; and leadership. The solution indicated that the changes in the leadership needed to relocate around the city. Previously, Kendal, Ison and Enoch (2012) explore the attitudes of stakeholders in terms of road pricing policy of the transportation planning process. The results showed that the sustainable leisure approach needs to be integrated with transportation planning, economic incentives that will support environmental awareness activities in sensitive environments leisure destinations.

More recently, sustainable development and environmental awareness increases in the construction industry of sustainable leisure has led to a decline negative impact on the environment during and after the construction phase and technological advances in the engineering and construction to support sustainable development. However, this raises the problem of lack of training or education to produce a construction professional, skilled and well understood the concept of sustainable development and construction associated with sustainable environmental laws. Therefore, academic institutions should participate and 
collaborate with relevant agencies in addressing the needs arising in the domain of sustainable recreation industry (Arain, 2014).

Nevertheless, Gladwin, Kennelly and Krause (1995) stated that the re-integration with the sustainable development based approach to science is more supportive organizational ecology and social aspects. Meanwhile, Welford, Ytterhus and Eligh (1999) and Williams and Millington (2004) review some of the literature and guidelines for business from the supply and demand sides, and they advocate both sides of the tourists through education, improve logistics management, and participation. While, Ostrom, Schroeder and Wynne (1993) and Banuri (2009) found a strong correlation between sustainable development and climate change that focuses on five pillars: adaptation, institutional arrangements, financial and technological support, decreased mitigation, and the development of the target country.

However, referred to elaboration on above discussion indicated that sustainable leisure consists of three domains (Kirkbride, 1999; Gladwin, Kennelly, \& Krause, 1995; Welford, Ytterhus, \& Eligh, 1999; Williams, \& Millington, 2004): local consensus, appraisals, and social carrying capacity. In detail, local consensus is a local community in participating in the sustainable leisure management (Hiwasaki, 2003). Secondly, the appraisal ensuring the favorable balance effects of leisure between environmental, sociocultural, and economic (Mikhaylovna, Yevgenyevna, \& Leonidovna, 2014), and Finally, the social carrying capacity as an assessment of the optimum number of people that be allowed without damaging the environment with social, cultural, and ecological approaches (Zacarias, Williams, \& Newton, 2011).

\section{Methodology}

The descriptive study was conducted over one year in Kuningan regency, West Java, Indonesia, from January 2012 - January 2013, with a combination of open questions on 200 respondents made up of local people, some tour operators, and related institutions. The data collected by purposive and stratified sampling technique by means of triangulation (Jenning, 2001): Structured interviews; Open interviews; and Observations. In addition, the data were tabulated by using a content analysis (Cohen, 1960), based on the concept of sustainable leisure: Exploratory analysis of sustainable leisure; Sustainable leisure parameters (Mavris, 2014; and Przeclawski, Pearce, Cohen, Lanfant, Dann, Pigram, Hawkins, \& Ritchie, 1993); Posting each Parameter of sustainable leisure; Frequency of sustainable leisure; Frequency calculated sustainable leisure; and Sustainable leisure tabulations were analyzed in more detail.

\section{Result and Discussion}

\subsection{The Linggarjati Natural Park}

The data was tabulated based on a content analysis (Cohen, 1960) which presented in Table 1, showed that Linggarjati Nature Park fulfills the requirements of sustainable leisure (Mavris, 2014; Przeclawski et al., 1993) and it's indicated by a Kappa coefficient $(K=0.735)$, which its meaning significant as it reflects on the appraisal ensuring the favorable balance effects of sustainable leisure's environmental, socio-cultural and economic as well. 
Table 1. Results of tabulation of Linggarjati Natural Park

\begin{tabular}{lrr}
\hline Parameter of Linggarjati Sustainable Leisure & Value & \% Freq \\
\hline Local community participation & 44 & 0.299 \\
Appraisal ensuring the favorable balance effects & 61 & 0.415 \\
Social carrying capacity & 42 & 0.286 \\
\hline
\end{tabular}

Kappa Coefficient $=\mathrm{K}=0.735$

In terms of local consensus, not far from the location of Natural Park is also a valuable historical building, the building site of the "Agreement between the Government of Indonesia Linggarjati with the Dutch government" which has a special attraction. The building is located in the village of Cilimus district, about 14 kilometers from the City of Kuningan. This village was built once after the first negotiations of Linggarjati between the Republic of Indonesia and the Netherlands in 11-13 November 1946. This event took time for three days for the negotiation that turned out to be a chain of history that can lift the name of a small building in the remote village became famous throughout the country, and even in different parts of the world. The building was later restored by the government in 1976 and used as well as heritage buildings and historical attractions (Nurhayatie, 2012).

Among the main content of the agreement Linggarjati, Dutch recognized the de facto Republic of Indonesia with the territory, including Sumatra, Java, and Madura. Republic of Indonesia and the Netherlands will cooperate in forming a United States of Indonesia, which is one part of the country is the Republic of Indonesia. And the United States of Indonesia and the Netherlands will make up the United Indonesian-Dutch with the Dutch Queen as its chairman.

Moreover, in terms of sociocultural, the Linggarjati Nature Park has a natural attraction in Kuningan District, and it is one of the starting points of climbing to Mount Ciremai. The land area of Linggarjati forest is about 11.51 hectares. It is designated as a Natural Park by the Minister of Agriculture In 1975, and this area is a separate part of the protected forest of Mount Ciremai defined since 1924 by the Dutch government. In addition, Nature Park Linggarjati have fresh cool air and the beautiful natural scenery.

Nevertheless, in terms of social carrying capacity, traveling along the Kuningan district, West Java, is less complete if it is not taking the time to visit some of the popular tourist crowded visited by every tourist who comes here. Historic buildings in Indonesia, located in the village of Linggarjati, District Cilimus, Kuningan District. Where is this building right at the foot of Mount Ciremai the southeast, to the north of the city of Kuningan or towards the south of the city of Cirebon. During the Japanese colonial era, the building was taken and used as "Hokai Ryokai" in 1942 then in 1945, the Republic of Indonesia successfully captures fighters and using it as the headquarters of the BKR and changed its name to Hotel Merdeka.

\subsection{Lake Remis}

Based on sustainable leisure (Mavris, 2014; Przeclawski et al., 1993) and a tabulation by a content analysis (Cohen, 1960) this study found Lake Remis potential to be sustainable 
leisure (Table 2). Lake Remis is located in the village of Kaduela, Kuningan, and it has a distance $37 \mathrm{~km}$ from the city center Kuningan. The name of this lake is taken from the name of an animal mussel, a type of yellow colored shells that many living around this lake.

The Forest Lake Remis is located at the foot of the mountain village of Ciremai. The distance is approximately $37 \mathrm{~km}$ from the mother city of Kuningan District, with a total area of approximately 13 hectares. While the area of vast lake of "Remis" is 3.25 ha, which is managed by Public Corporation Forestry Kuningan District. This forest having a value of its own history and quite impressive, if we always scour the history of war kingdoms 16 th century.

Table 2. Results of tabulation of the lake Remis

\begin{tabular}{lrc}
\hline Parameters of Lake Remis Sustainable Leisure & Value & \% Freq \\
\hline Local community participation & 40 & 0.308 \\
Appraisal ensuring the favorable balance effects & 52 & 0.400 \\
Social carrying capacity & 38 & 0.292 \\
\hline
\end{tabular}

Kappa Coefficient $=0.650$

Sightseeing of lake Remis Kuningan, the tourists can enjoy the scenic of a large lake with clear water surrounded by pine trees and mountains surrounding atmosphere makes it the panoramic sights was very beautiful, natural landscape so verdant in this lake to become evident, "Talaga Remis" that's the name of these attractions. Interesting activities are often carried the tourists enjoying the beauty of this lake, circling the lake with water using a boat bicycle, a wooden boat or motor boat. "Talaga Remis" is a tourist spot in Kuningan district, which has a natural grace of the exotic blend of natural charm with the combinations scenic of mountains, forests and crystal clear lake water. While, the access to lake Remis still limited. Therefore, Kuningan government should build synergies between sustainable recreation location, especially for the facilities and infrastructure. That's the reality of identifying gaps today.

However, "Talaga Remis" has a beautiful view of the mountains and lakes with clear water, making it perfect for travel. Most tourists who visit to spend time with enjoying the typical food in the form of carp which is widely available in the restaurant-restaurant here, in addition to enjoy the water by using a water bike or boat, or just a walk enjoying the view of the lake and forest with clean air. Another attraction of this place is the presence of a rare plant species, namely Banana Hyang becomes cultural attractions are well-known both in domestic and foreign (Sahidah, 2012).

\subsection{Waterfall Ciputri}

Results of tabulation of the Waterfall Ciputri (Table 3) based on sustainable leisure (Mavris, 2014; Przeclawski et al., 1993) and content analysis (Cohen, 1960), indicating significant (K $=0.665)$. Based on the local consensus, the tourists can visit the National Park of Mount 
Ciremai, and they can enjoy the natural scenic in the Palutungan village to enjoy the fresh waterfalls. In this region contained several interesting leisure activities which should be tried along with a family, friends or close relatives as swimming, playing in the cool and clear water naturally. With the travel time is only 10 minutes from the entrance Palutungan, passing some stairs that made the tourists was shortly going to arrive. If they want to swim around the size of the waterfall, they can cross a small stream and climb a bit to enjoy the cool water straight down from a height of nearly 12 meters.

Table 3. Results of tabulation of the Waterfall Ciputri

\begin{tabular}{lrr}
\hline Parameters of Waterfall Ciputri Sustainable Leisure & Value & \% Freq \\
\hline Local community participation & 41 & 0.308 \\
Appraisal ensuring the favorable balance effects & 55 & 0.414 \\
Social carrying capacity & 37 & 0.278 \\
\hline
\end{tabular}

Kappa Coefficient $=0.665$

Waterfall Ciputri is located at the foot of Mount Ciremai, exactly in the Village District of Cigugur Cisantana, there is a coniferous forest in addition to serve as the location Campgrounds also became one of the tourist destinations in Kuningan. Waterfall Ciputri is located at the foot of Mount Ciremai, which having a beautiful panoramic pine forests and the air is cool. A Ciputri waterfall named because it is said, according to local legend, there dwells a beautiful princess who keeps the waterfall.

To get there, the tourists had to pass through the path downward and terraces with plants and bushes on the left and right. The atmosphere is cool and has noticeably cooled so the tourists tread the path, gurgling sound of the waterfall has also accompanied the sound of the steps of the tourists. On the rainy season, the tourists should be more careful when walking towards the waterfall Ciputri, because the path that they through unspoiled made of ground, so it can become slippery when exposed to rain. While, in this study found that there is the gap between the beauty of the waterfall destinations Ciputri and infrastructure facilities are still in the development stage. Therefore, the Kuningan government must build synergy between sustainable recreation location, especially for facilities and infrastructure.

However, the tourists can see the wonderful waterfall surrounded by verdant cliffs, which overgrown bushes, and the waterfall which is just as high as twelve feet there are in a valley that is not so wide. Under a Ciputri waterfall, there is a pool of clear water formed like a pond that is not too broad, which was only about thirty centimeters, with decorated stones in the bottom and there are also several large rocks that have moss, so add a beautiful atmosphere in Ciputri's waterfall. The cliffs are also often used as a training event for nature lovers for rock climbing (Inside, 2011).

\subsection{Archaeological Park Cipari}

Based on sustainable leisure (Mavris, 2014; Przeclawski et al., 1993) and tabulated by content analysis (Cohen, 1960) of the Archeological Park Cipari (Table 4) indicated that the 
Archaeological Park Cipari could be sustainable leisure $(K=0.695)$. A Cipari Archaeological Park is located in the Village Cipari, Cigugur village, sub-district at the foot of the Mount Ciremai Cigugur East. Archeological Sites Cipari discovered in 1972. They found a tombstone coffin, the other findings in the form of stone tools, pottery, bronze, and traces of prehistoric building foundation.

In terms of sociocultural, Kuningan charm also has an interesting cultural attractions, one of which is the site Cipari which indicates that this area has been inhabited by humans since prehistoric times, or about 3,500 years BC. This study found that the site of Cipari had a twice period of settlement. Firstly, is on the late Neolithic, and secondly on the early bronze material introduction in $1000 \mathrm{BC}$ until $500 \mathrm{AD}$ or the Megalithic period (Zmalarangeng, 2011).

Table 4. Results of tabulation of the Archaeological Park Cipari

\begin{tabular}{lrr}
\hline Parameters of Archaeological-Cipari Sustainable Leisure & Value & \% Freq \\
\hline Local community participation & 42 & 0.302 \\
Appraisal ensuring the favorable balance effects & 60 & 0.432 \\
Social carrying capacity & 37 & 0.266 \\
\hline
\end{tabular}

Kappa Coefficient $=0.695$

Archaeological Sites Cipari a heritage site of the megalithic era of ancient peoples who lived in the Great Sunda land, the terrain which includes Sumatra, Java, and Borneo, and the sea which links all three in about 10,000 years ago. Additionally, the attractive tourist spots on this site is also equipped with a museum which also saves a story of ancient times. Trajectory of human life in the prehistoric megalithic times the tourists can visit the sites Ciparigi in their leisure time and at the same time can be an educational material to be learned.

A patterned megalithic park located in the Village Cipari, District Cigugur, is one where the discovery of prehistoric cultural relics in Kuningan District. With an area of 6364 square meters, is found three grave stone coffin in which there is provision of a grave stone axes, stone bracelets, and pottery.

Here also we can see the terrain circular with a diameter of six meters with limited rock composition shingle. Meeting Stone Bracelet, formerly believed to be the location where the ceremony in connection with the ancestors, as well as serving as a place of deliberation.

There also a grave coffin, which made of an "Andesite" stone shaped shingle is composed in its place, leads northeast to southwest that illustrates the concepts of natural power, such as the sun and moon are a way of life from birth to death. In the west of the gravestone, after a Menhir there is a terrace and some dolmen (stone table) which is composed of a wide stone which was supported by several other stones that shaped table. Among the stone dolmen, also Dakon stone (stone mortar), serves as a place to make a concoction of drugs. "Dolmen function as a place of worship to the ancestors at the same time laying the offerings" (Sari, 2013). 


\section{Conclusions}

This study found four potential sustainable tourism based on sustainable leisure (Mavris, 2014; Przeclawski et al., 1993) in Kuningan District. Firstly, the Linggarjati Natural Park is the most potential to be a sustainable leisure park, which the performance of social carrying capacity could be more improved in the future as long the Kuningan government intents to communicate and educate the stakeholder, especially local people, and tour operator in managing, developing, and balancing each parameter of sustainable leisure. Secondly, Archaeological Park Cipari is more potential to be a sustainable leisure park, which social carrying capacity becomes the issue that would be the first priority of the Kuningan government's in the developing plan of a home stay, natural logging, transportation and on supporting the balance performance of sustainable leisure in the very near future. Thirdly, Waterfall Ciputri is potential to be a sustainable leisure waterfall, where social carrying capacity becomes the first issue of responding and accommodating tourists' satisfaction, especially on improving their infrastructure and it is better integrated with the infrastructure settlement of the Kuningan government plans. Finally, Lake Remis is also potential to be a sustainable leisure lake, where social carrying capacity becomes the first priority on enhancing the performance of sustainable leisure by the development of an infrastructure, natural logging, clean area, and maintenance plan on responding tourists need. However, this research found that social carrying capacity and social consensus become a big issue in improving appraisal and performance of sustainable leisure in Kuningan. At the same time, it could responding tourists' need and their expectation

\section{Implications}

In the following discussion, this study will try to criticize the three issues (Przeclawski et al, 1993) above. Firstly, developing and building an attraction designed to be a comprehensive spatial pattern, although the development of these facilities is not built all at once. However, with comprehensive planning, all the facilities will be built according to the design that was created from the beginning. Secondly, to continuously align the dynamics of development, the tourism sector as one of the leading sectors should receive top priority in its development. So that the regional and international tourists will always get a new feel when visiting the attractions in Kuningan. In addition to poor development, attraction of cleanliness element was not taken seriously. Although impressed trivial, but the cleanliness of an area gives a positive image and provide perfect comfort in addition to entertainment and beautiful scenery for a tourist. Finally, a development of any sustainable leisure should have a long-term of designing and planning that will be the foundation for the development.

\section{References}

Aall, C. (2010). Energy use and leisure consumption in Norway: an analysis and reduction $\begin{array}{lllll}\text { strategy. Journal of } & \text { Sustainable } & \text { Tourism, } & \text { 19(6), }\end{array}$ http://dx.doi.org/10.1080/09669582.2010.536241

Arain, F. (2014). Enhancing sustainability practices in Canadian construction industry: a case for an academic program in sustainability, OIDA. International Journal of Sustainable 
Development,

$7(4)$

101-108.

Retrieved

from

http://papers.ssrn.com/sol3/papers.cfm?abstract_id=2492620\#\#

Asdhiana, I. M. (2014). Sustainable Tourism Improve the Quality of Life of the People, Kompas, Travel Kompas. Retrieved from http://travel.kompas.com/read/2014/09/18/090600027/Pariwisata.Berkelanjutan.Tingkatkan. Kualitas.Hidup.Rakyat

Banuri, T. (2009). Climate change and sustainable development, Natural Resources Forum, $33(4), 257-258$.

Cohen, J. (1960). A Coefficient of Agreement for Nominal Scales. Educational and Psychological, 20, 37-46. http://dx.doi.org/10.1177/001316446002000104

Edginton, C. (2013). History of the world leisure organization: a 5-year perspective and $\begin{array}{llll}\text { analysis. World } & \text { Leisure }\end{array}$ http://dx.doi.org/10.1080/04419057.2013.820506

Farhan, A. (2014). This challenge Tourism Development in Indonesia, Detik.com. Retrieved from

http://travel.detik.com/read/2014/02/06/180115/2489642/1382/ini-tantangan-pengembanganpariwisata-di-indonesia

Gladwin, T. N., Kennelly, J. J., \& Krause, T. (1995). Shifting paradigm for sustainable development: Implications for management theory and research. ACAD MANAGE REV, 20(4), 874-907. http://dx.doi.org/10.5465/AMR.1995.9512280024

Gordon, C. (1991). Sustainable leisure. Journal Ecos, 12(1), 7-13. Retrieved from http://www.cabdirect.org/abstracts/19911896837.html;jsessionid=2B60492EECC14309F024 2C3EE402EAEF

Hiwasaki, L. (2003). Tourism in Japan's parks and protected areas: challenges and potential for sustainable development. Journal International Review for Environmental Startegies, 4(1), 107-126. Retrieved from http://www.cabdirect.org/abstracts/20043131558.html

Ho, C., Liao, T., Huang, S., \& Chen, H. (2014). Beyond environmental concerns: using means-end chains to explore the personal psychological values and motivations of leisure, recreational cyclists. Journal of Sustainable Tourism. http://dx.doi.org/10.1080/09669582.2014.943762

Inside, C. (2011). Cool waterfall Waterfalls Ciputri, Cirebonis.blogspot.com. Retrieved from http://cirebonis.blogspot.com/2011/05/sejuknya-air-terjun-curug-ciputri.html

Jenning, G. (2001). Tourism Research (pp. 136-152). John Willey \& Sons Australia, Ltd.

Kendal, J., Ison, S., \& Enoch, M. (2012). UK National Parks: a role for road pricing? Sustainable Transportation, 5(1), 25-42. http://dx.doi.org/10.1080/15568310903312143

Kirkbride, C. (1996). Managing for sustainable leisure in the countryside - have we begun? Journal Ecos,

17(3/4),

10-17.

Retrieved

from 
http://www.cabdirect.org/abstracts/19971809534.html

Mavris, C. (2011). Sustainable Environmental Tourism and Insular Coastal Area Risk Management in Cyprus and the Mediterranean. Journal of Coastal Research: Special Issue 61, 317-327. http://dx.doi.org/10.2112/SI61-001.1

Mikhaylovna, K. T., Yevgenyevna, D. L., \& Leonidovna, S. N. (2014). Rural Tourism and Sustainable Development of Rural Territories. World Applied Sciences Journal, 30, 104-106. http://dx.doi.org/10.5829/idosi.wasj.2014.30.mett.51

Miller, G., Rathouse, K., Scarles, C., Holmes, K., \& Tribe, J. (2007). Public understanding of sustainable leisure and tourism: A report to the Department for Environment, Food and Rural Affairs. University of Surrey. Defra, London. Retrieved from file://D:/ACER\%20AUGUST\%202014/J-DEVELOPMENT/ST\&L\%20report.pdf

Nurhayatie, H. (2012). Tourism glimpse district Kuningan, Attractions in Kuningan. Retrieved from http://heppiinurhayati.blogspot.com/2012/12/objek-wisata-di-kuningan.html

Ostrom, E., Schroeder, L., \& Wynne, S. (1993). Institutional incentives and sustainable development: infrastructure policies in perspective, Science Direct, 283. Retrieved from http://www.cabdirect.org/abstracts/19936716128.html

Przeclawski, K., Pearce, P. L., Cohen, E., Lanfant, M. F., Dann, G. M. S., Pigram, J. J., Hawkins, D. E., \& Ritchie, J. R. B. (1993). Tourism research: critiques and challenges, CAB Direct, $227 . \quad$ Retrieved from http://www.cabdirect.org/abstracts/19931856039.html;jsessionid=5640F233AAC7999109573 4C9ADBA5F1C

Sahidah, D. (2012). Remis Lake, Tourism in West Java. Retrieved from http:/www.tempatwisatadijawabarat.com/2012/12/talaga-remis.html

Santosa, S. P. (2004). Recognize the competitiveness of tourism, Indonesia. Retrieved from http://kolom.pacific.net.id/ind/setyanto_p._santosa/artikel_setyanto_p._santosa/mengenali_da ya_saing_pariwisata_indonesia.html

Sari, N. (2013). Nature Park Linggarjati, Kuningan.blogspot.com. Retrieved from http://kabupaten-kuningan.blogspot.com/2013/04/tempat-wisata-linggar-jati-kabupaten.html

Schuttemeyer, A., Fobker, S., Ramatschi, G., \& Grotz, R. (2004). Elderly people on the road: an approach to a more sustainable leisure mobility. Erdkunde, $B d$ 58(H1), 17-30. Retrieved from http://www.jstor.org/discover/10.2307/25647629?uid=2\&uid=4\&sid=21104206393201

Stebbins, R. A. (2011). Leisure studies: the road ahead. World Leisure Journal, 53(1), 3-10. http://dx.doi.org/10.1080/04419057.2011.552197

Welford, R., Ytterhus, B., \& Eligh, J. (1999). Tourism and sustainable development: an analysis of policy and guide for managing provision and consumption. Sustainable Development, $7(4)$ 165-177. http://dx.doi.org/10.1002/(SICI)1099-1719(199911)7:4<165::AID-SD117>3.0.CO;2-F 
Williams, C. C., \& Millington, A. C. (2004). The diverse and contested meanings of sustainable development. The Geographical Journal, 170 (2), 99-104. http://dx.doi.org/10.1111/j.0016-7398.2004.00111.x

Wooler, J. (2014). Exploring the Potential of Social Marketing to Encourage Sustainable Tourist Behaviour in South West England (Doctoral dissertation). Available from Open Research Exeter (ORE).

Zacarias, D., Williams, A. T., \& Newton, A. (2011). Recreation carrying capacity estimations to support beach management at Praia de Faro, Portugal. Applied Geography, 31(3), 1075-1081. http://dx.doi.org/10.1016/j.apgeog.2011.01.020

Zmalarangeng (2011). Tourism Object of Regency Kuningan, Zuhry.blog.com. Retrieved from http://zuhry.blog.com/2011/04/21/obyek-wisata-kabupaten-kuningan/

\section{Copyright Disclaimer}

Copyright for this article is retained by the author(s), with first publication rights granted to the journal.

This is an open-access article distributed under the terms and conditions of the Creative Commons Attribution license (http://creativecommons.org/licenses/by/3.0/). 